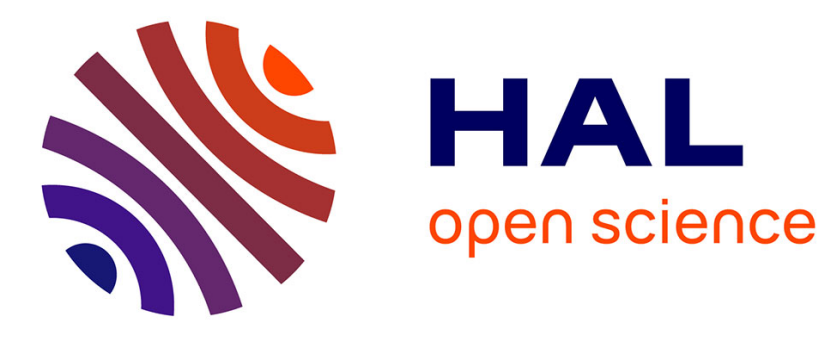

\title{
The Barnett Allocation Mechanism: Formula plus Influence?
}

Kim Swales, Alex Christie

\section{To cite this version:}

Kim Swales, Alex Christie. The Barnett Allocation Mechanism: Formula plus Influence? Regional Studies, 2010, 44 (06), pp.761-775. 10.1080/00343400903107710 . hal-00600457

\section{HAL Id: hal-00600457 https://hal.science/hal-00600457}

Submitted on 15 Jun 2011

HAL is a multi-disciplinary open access archive for the deposit and dissemination of scientific research documents, whether they are published or not. The documents may come from teaching and research institutions in France or abroad, or from public or private research centers.
L'archive ouverte pluridisciplinaire HAL, est destinée au dépôt et à la diffusion de documents scientifiques de niveau recherche, publiés ou non, émanant des établissements d'enseignement et de recherche français ou étrangers, des laboratoires publics ou privés. 


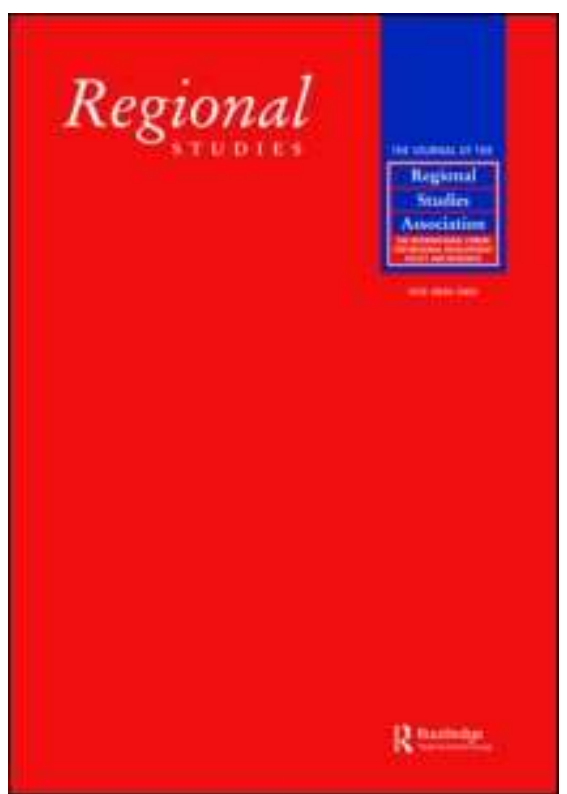

The Barnett Allocation Mechanism: Formula plus Influence?

\begin{tabular}{|r|l|}
\hline Journal: & Regional Studies \\
\hline Manuscript ID: & CRES-2007-0097.R1 \\
\hline Manuscript Type: & Main Section \\
\hline JEL codes: & $\begin{array}{l}\text { H70 - General < H7 - State and Local } \\
\text { Government|Intergovernmental Relations < H - Public Economics, } \\
\text { Rural, and Regional Economics }\end{array}$ \\
\hline Keywords: & Barnett formula, Bargaining, Peripherality \\
\hline
\end{tabular}

\section{scholarONE \\ Manuscript Central}




\title{
The Barnett Allocation Mechanism: Formula plus Influence?
}

\author{
Alex Christie, Fraser of Allander Institute, Department of Economics, University of \\ Strathclyde, Sir William Duncan Building, 130 Rottenrow, Glasgow G4 0GE \\ alexander_christie@hotmail.com \\ J.Kim Swales, Department of Economics, University of Strathclyde, Sir William Duncan \\ Building, 130 Rottenrow, Glasgow G4 0GE \\ j.k.swales@strath.ac.uk
}

(Received April 2007: in revised form December 2008) 


\begin{abstract}
This paper seeks to explain why the operation of the Barnett formula has failed to generated convergence in the per capita public expenditure levels in the four countries of the UK. Using Scotland as an example, the paper argues that a 'formula plus influence' allocation mechanism has been in place. This offers improved flexibility, greater political integration and increased information flows than would be available through either a straight bargaining or formula process. While devolution has not changed the Barnett formula, it has altered the environment in which it operates and that this may well destabilise an otherwise secure system.
\end{abstract}

Key words: Barnett Formula, Devolution, Fiscal Decentralisation, Scotland, Public Finance

巴奈特分配机制：程式累积影响？区域研究。本文试图解释为何巴奈特程式未能使 英国四个国家的人均公共支出产生汇聚效应。以苏格兰为例，文章认为

“ 程式累积影响”分配机制发挥了作用。较之通过直接谈判或者程式过程可能产生 的结果而言，“程式累计影响”提供了更大的机动性、较多的政治整合以及更为充 沛的信息流。权力向地方的转移并未改变巴奈特程式, 却改变了操作环境, 从而可 能使原本安全的系统变得不太稳定。

प्र०
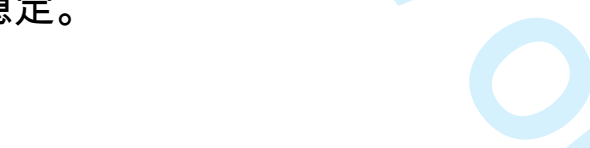

La méthode d'affectation Barnett: formule plus influence?

Cet article cherche à expliquer pourquoi l'application de la formule Barnett n'a pas réussi la convergence des dépenses publiques par tête dans les quatre pays du R-U. En se servant de l'Ecosse comme étude de cas, l'article affirme qu'une méthode d'affectation 'formule plus influence' a été en vigueur. Cela fournit une flexibilité augmentée, une intégration politique plus importante et des flux d'information accrus qui n'auraient été 
disponibles par moyen de simples négociations ou d'une simple formule. Tandis que la régionalisation n'a eu aucun impact sur la formule Barnett, elle a changé le milieu auquel il se voit appliquer, et cela pourrait bien déstabiliser un système par ailleurs solide.

Formule Barnett, Régionalisation, Décentralisation fiscale, Ecosse, Finances publiques

Der Barnett-Zuweisungsmechanismus: Formel plus Einfluss?

Alex Christie and J.Kim Swales

In diesem Beitrag wird eine Erklärung für die Frage gesucht, warum sich mit der BarnettFormel in den vier Ländern des Vereinigten Königreichs keine Konvergenz hinsichtlich der Höhe der öffentlichen Pro-Kopf-Ausgaben erzielen lässt. Anhand des Beispiels Schottland wird argumentiert, dass bei der Zuweisung ein Mechanismus von der Art 'Formel plus Einfluss' zum Einsatz kam. Dies führt im Vergleich zu einem einfachen Verhandlungs- oder Formelprozess zu einer Verbesserung der Flexibilität, der politischen Integration und des Informationsflusses. Die Dezentralisierung hat die Barnett-Formel nicht verändert, wohl aber die Umgebung, in der sie zum Einsatz kommt, was durchaus zur Destabilisierung eines ansonsten sicheren Systems führen kann.

Keywords:

Barnett-Formel, Dezentralisierung, Fiskale Dezentralisierung, Schottland, Staatsfinanzen

El mecanismo de la asignación Barnett: ¿fórmula más influencia?

El objetivo de este artículo es explicar el porqué la operación de la fórmula Barnett no ha generado una convergencia en los niveles de gastos públicos per cápita en las cuatro regiones del Reino Unido. Usando Escocia como ejemplo, en este ensayo argumentamos que se ha introducido un mecanismo de asignación tipo 'fórmula más influencia'. Esto ofrece una mejor flexibilidad, mayor integración política y más flujos de información comparado con un proceso a través de negociaciones directas o de fórmulas. Aunque la transferencia de competencias no ha cambiado la fórmula Barnett, sí que ha alterado el entorno en el que funciona y esto bien podría desestabilizar un sistema que normalmente es seguro.

Keywords:

Fórmula Barnett, Transferencia de competencias, Descentralización fiscal, Escocia, Finanzas públicas

JELCodes H79, R 50 


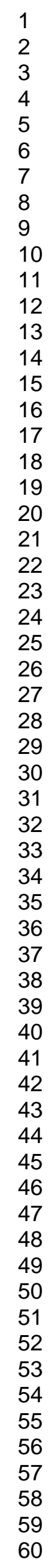




\section{Introduction}

Since 1978, the Barnett formula has been the mechanism that formally determines the distribution of the bulk of public funds from the UK central government to the administrations in Northern Ireland, Scotland and Wales, the three regions of the UK that are not part of England. Whilst the UK central government does not deal with these three regions uniformly, their treatment has always differed from that of the English regions, and this difference was further extended when the post-1997 UK Labour government devolved their administrations. In this paper we refer to Northern Ireland, Scotland and Wales collectively as the UK peripheral regions or, where appropriately, the UK devolved administrations

Despite being used by successive Conservative and Labour governments, the Barnett formula has been the subject of vigorous debate and often-adverse comment. This has centred round its fairness and rationality and its implications for the future funding of the UK devolved administrations. In terms of fairness, MacKay (2001, 2005) and McLean and McMillan (2003) point to the relatively generous treatment of the UK peripheral regions, especially Scotland, when set against "comparable" English regions. Concerning rationality, the Barnett formula has a very weak link with need. Further, the operation of the formula should generate relative per capita public expenditure convergence in the peripheral regions to the average English level (Bell, 2000; Cuthbert, 1998; Ferguson et al, 2003; Heald, 1994; Kay, 1998; Midwinter, 1999). ${ }^{1}$ However, even 
those who take the existing UK spatial allocation of public expenditure to be unfair, find such ultimate convergence in per capita expenditure undesirable.

This paper has four key interrelated themes. First, we follow Alesina and Spolaore (1997, 2003), who argue that from an economic point of view, as a country increases in geographical scale, two conflicting influences apply. On the one hand, the per capita costs of providing national public goods, such as defence and foreign affairs, falls. On the other, increased size will also, in general, be associated with greater population diversity. From such a perspective, it is likely to be optimal for the government to treat regions that are geographically and culturally distanced from the centre favourably on efficiency grounds, to prevent secession, and on equity grounds, because peripheral regions gain least from a uniform tax and expenditure system. In this approach, the relatively favourable existing treatment of the UK peripheral regions is both explicable and justifiable.

The second theme is that the actual per capita government expenditure will be influenced by the government's response to short-term region-specific shocks. However, such shocks will generate fluctuations around an underlying relative per capita expenditure level that is comparatively stable over time. This stable underlying position reflects the bargaining position of the region with the centre, which depends partly on the region's ability to secede. Because this is relative bargaining position will change only slowly with time, we expect the relative per capita expenditure levels to be similarly stable. 
The third theme is that the Barnett formula is only part - albeit a very important part - of the system that determines appropriate public expenditures in the UK peripheral regions. This more extensive system has maintained relatively stable per capita public expenditure differences between the peripheral and English regions. We show that there is no necessary contradiction in a mechanism that, if operating alone, would generate relative public expenditure convergence, being part of a system generating such stability. In particular, we give a "formula plus influence" account of this process that is credible, consistent with the available evidence and has benefits for both the centre and peripheral regions.

The fourth theme is that whilst the Barnett formula did not change fundamentally with devolution, the institutions around it did. As a result this rather subtle system, of which the Barnett formula was a part, seems more appropriate for the pre-, rather than post-, devolution administrative and political arrangements. The funding of the UK devolved administrations is likely to pose extremely difficult questions in the future.

In Section 2, we outline two major puzzles of the Barnett formula: the lack of evidence of relative public spending convergence and the lack of transparency in the operation of the formula. In this section we provide additional Scottish data pointing to such non-convergence. In Section 3 we discuss alternative accounts that place the Barnett formula in a richer institutional setting. In particular we consider Heald's notion of "formula by-pass" and Midwinter's arguments around bargaining. In Section 4 we 
present our alternative representation of the funding mechanism, a "formula plus influence" system. Section 5 discusses the way in which devolution has led to changes in this procedure and Section 6 is a short conclusion. Whilst the arguments apply generally to the UK peripheral regions, we often take Scotland as an exemplar, given better data for Scotland and the more virulent debate that has emerged there around the Barnett formula.

2. Puzzles concerning the operation of the Barnett formula

There are two major puzzles associated with the operation of the Barnett formula. These concern the observed lack of convergence in per capita public expenditure in the peripheral regions and the low level of transparency in the workings of the formula.

\subsection{Lack of convergence}

The Barnett formula was introduced in 1978 , linked to the proposal to establish devolved assemblies for Scotland and Wales. In the case of Scotland initially the formula delivered 10/85ths of changes in comparable spending conducted in England. This transfer was known as the Scottish block: 10/85 matched the population ratio between Scotland and England at the time of the formula's establishment. ${ }^{2}$ The details of the operation of the formula have changed over the period of its use, but not the broad principles. It has only ever acted on marginal changes in the various forms of comparable expenditure between England and peripheral regions (Official Report, 1997). In the absence of population change this means that any initial absolute differences in per capita 
public spending allocations - the appropriate comparison - are perpetuated by the formula. $^{3}$

As a result of changes in public accounting introduced by the post-1997 Labour Government, the formula now acts on most of that part of the budget termed Departmental Expenditure Limits (DEL). This section of the budget is set on a three-year cycle as part of the Spending Review process. DEL covers items deemed to be predictable and therefore able to be planned, for example health and education. ${ }^{4}$ The other part of the new budget process, Annually Managed Expenditure (AME), is outwith the formula. Its components, as the name suggests, are determined annually, largely because they are demand led. An example is social security payments.

The logical implication of operating such a system is that with increased nominal government expenditure, relative public spending per head in the peripheral regions will converge on the English spending level. ${ }^{5}$ This is because the per capita spending increment is the same across administrations and the effect of the different initial starting levels becomes proportionately less important with time. Whilst there are constraints on this convergence, it is generally agreed that the Barnett formula should, in practice, lead to convergence in per capita spending if it is applied correctly to large parts of the budget increment. This predicted convergence is known as the Barnett squeeze (Bell, 2000; Cuthbert, 1998; Heald, 1994; Kay, 1998). ${ }^{6}$ 
However, the actual, as against predicted, performance of the formula is much more difficult to determine. Data concerning UK public spending on a regional basis are limited, though improving, and are most easily accessed in the annual Public Expenditure Statistical Analyses (HM Treasury). But, these figures are for identifiable expenditure, and while spending is classified by government level it is based on output expenditure rather than any input allocation. Details derived from the Scottish and Welsh budget documents show additions to AME and DEL, but not what proportion of the DEL increase was determined by the Barnett formula. Equally, the biennial Statement of Funding Policy (HM Treasury) gives the comparability percentages, population relativities and total spending allocations to each spending line, but not the increments for any one year. While information on public spending has increased greatly, it is still not detailed enough to know the precise Barnett allocations and therefore whether convergence through the operation of Barnett has or has not taken place.

Previous studies (Bailey and Fingland, 2004; Midwinter, 2002) have used identifiable expenditure per head over time. They demonstrate a lack of convergence towards the English per capita spending allocation, with Bailey and Fingland finding spending levels per head in Northern Ireland and Wales converging to the Scottish, rather than English, level. Gallagher and Hinze (2005) similarly focus on identifiable expenditure, but here excluding social protection and agriculture and covering only the post-devolution period. ${ }^{7}$ They claim to detect convergence but this seems premature. There is no convergence in the Welsh figure and the large fall in Northern Irish relative expenditure per head is likely to be driven by factors specific to that province. 
Heald and McLeod (2002) correctly note that it is potentially misleading to use this data source to identify the impact of the Barnett formula since identifiable expenditure includes expenditure by all levels of government and not just that undertaken as a consequence of Barnett formula funding. Bailey and Fingland (2003) particularly stress this point. Removing social security expenditure and agriculture, the largest UK government expenditures in Scotland and Wales, gets closer to the Barnett funded expenditures. However, although this adjustment alters spending patterns, the data still do not indicate that relative convergence in spending per head has occurred.

We approach this issue in a slightly different way, using information based on budget inputs, rather than the spending outputs previously employed. ${ }^{8}$ Specifically, we calculate the Scottish budget allocation per head as a percentage of the corresponding UK figure for the period 1982 to 2005. These figures are not perfect for this task. Not only are they aggregate data, and there are minor changes in their composition from time to time, but also the measurement criteria altered during the period under examination. However, whilst Heald and McLeod's (2002) comments remain valid here too, if there has been convergence in spending per head, then over this extended period something should be apparent. And with no official information on Barnett consequential spending available, this at least offers a perspective using a different data set. Given the findings of previous studies using expenditure data, if input data also show no sign of convergence, we feel it is reasonable to conclude that systematic forces are at work which, up to now at least, have thwarted convergence. 


\section{FIGURE 1 NEAR HERE}

Figure 1 shows the relative budget allocations per head over the twenty-three year period up to 2005. A few caveats about this comparison must be borne in mind. Ideally the comparison would be with English budget allocation per head, but this is not possible due to lack of English data. Using the UK budget per head means incorporating items of expenditure calculated using the Barnett formula (funding for Wales and Northern Ireland) and non-identifiable expenditure for the benefit of the UK as a whole not covered by the formula.

However, in order to get as close as possible to a figure for an English per capita budget we have excluded certain items from our calculations. We have subtracted funding for Scotland, Wales and Northern Ireland, since these are clearly identifiable, from the UK budget sums. In addition we have excluded those items that are largely to the benefit of the UK as a whole: Defence, Foreign and Commonwealth Office expenditure and funds for International Development/Overseas Development Agency. Social Security expenditure has also been removed since it is demand led. These exclusions do not create an England only budget, but they do remove the vast bulk of whole-UK budgeted expenditure and all non-English identifiable budgets and present a reasonable indicator of planned expenditure in England.

There is little remarkable about the relationship between Scottish and UK per capita budget allocations, other than its stability. Throughout this period the Scottish 
population fell as a percentage of the UK population, from $9.2 \%$ in 1982 to $8.5 \%$ in 2004 . From 1978 until 1992 Scotland's population within the Barnett formula was fixed and as a result of this discrepancy Scotland would have received more funds through the formula than it warranted. However, the formula was re-based in 1992 and subsequently annually updated from 1997. There is no evidence from Figure 1 that per capita budget allocation in Scotland fell relative to the UK due to the effect of the formula, nor that changing population shares led to step changes. At the end of the period, the Scottish relative per capita budget allocation remained exactly as it had been 23 years earlier. Over the whole period, the Scottish per capita budget allocation was $17 \%$ higher than the UK figure and there is no statistically significant pattern of increases or decreases. ${ }^{9}$ Similarly, whilst others point to the Barnett squeeze operating in the post-devolution period, this is not apparent from these data.

This evidence is reinforced by the views of key insiders that regional spending convergence is not a function of the operation of the Barnett formula. This is so, even though it has been clearly demonstrated that, save under exceptional circumstances, this is precisely the outcome of the strict imposition of the formula when nominal public expenditure is increasing. For example, Ros Dunn, Head of HM Treasury Devolved Countries and Regions team, claimed to the House of Lords Select Committee on the Constitution (Official Report, 2002, Q1263) that 'it is important to note that ... convergence is not a property of the formula as it stands'. Similarly, Professor Arthur Midwinter (2004), then adviser to the Scottish Parliament's Finance Committee, claims 
that no public document or ministerial statement has ever asserted that convergence is an aim of the Barnett formula. He also argues that:

convergence on spending [is] "not a policy objective" of the UK Government, and that any of the devolved administrations - Scotland, Wales and Northern Ireland could reopen the formula if they believed it was not providing resources relative to its need (The Scotsman, $24^{\text {th }}$ June, 2005).

\begin{abstract}
Midwinter asserts that there is no evidence from spending data to justify consistent convergence between Scottish and English per capita spending. Rather spending has fluctuated around $125 \%$ of the UK expenditure per head total since 1992. Our data analysis is broadly in line with his findings.
\end{abstract}

\title{
2.2 Lack of transparency
}

Donald Dewar presents the standard view that:

... successive Governments have defended [the Barnett formula] for many years because it is simple and explicable....[I]t is a neat and tidy method of adjusting Scottish expenditure so that it is in line with that of comparable Departments south of the border. I expect that to continue. (Official Report - Scottish Grand Committee, $21^{\text {st }}$ July 1998 , column 6) 
This defends the idea that the formula works as the Statement of Funding Policy describes, since a 'neat and tidy method' is doubtless a computational one.

From a purely economic perspective, certain aspects of the mechanics of the formula have potentially beneficial efficiency outcomes. First, having a formula that is ostensibly free of political manipulation reduces influence costs. In fact, if the formula were complete, and if transfers outwith the Barnett formula were to consist only of AME (demand-led) spending, these influence costs would be zero. Second, the formula also provides economic stability, since budget growth is incremental rather than zero-based. If budgets were re-based every year, stability would be greatly reduced and influence costs increased since, in its current form, the spending whims of English departments would determine entirely the outcomes for the peripheral regions. Instead, under the operation of the Barnett formula the budgets of the peripheral regions are based almost entirely on historical budget priorities of the Whitehall departments and only marginally on current priorities. Third, the Barnett system imposes a hard budget constraint. A strict formulabased approach means that the devolved administrations are not bailed out when they make policy mistakes. The sharpening of financial accountability that accompanies a hard budget constraint is thought to improve public decision taking. Hallwood and McDonald $(2005 ; 2006)$ make this point with particular force.

These advantages require that the Barnett formula should be transparent. But as we have argued in the previous subsection, the actual operation of the Barnett formula is curiously opaque. In its early years the formula was little understood, with most 
information coming through academic research rather than the government. This changed with the publication of a Written Answer to a parliamentary question in 1997 where the process employed by the formula was set out (Official Report, 1997). More recently, how the Barnett formula is technically calculated has become common - if occasionally misconstrued - knowledge. However, the data required to track the precise manner in which spending increases in England lead to the subsequent increases in the sums available to Scotland, Wales and Northern Ireland are still not publicly available. The Barnett mechanism cannot be verified independently and the relationship between the published Barnett process and the budget outcomes is still hidden from scrutiny. ${ }^{10}$

\section{Bargaining not Barnett}

Whilst the Statement of Funding Policy maintains that the Barnett process is purely formula-driven, the evidence presented in the previous section suggests that it is not. An explanation for the actual figures is that in reality the outcome is the result of a bargaining process. This theory has a weak and strong form. Heald (1994) presents the weak form when he argues that failure of per capita spending to converge is a result of making extra payments outwith the formula. These "formula by-pass" payments may vary from year to year, but independently of whether these payments are large or small, systematic or ad hoc, they would act to erode the convergence features of the formula. He gives examples of how expenditure allocation outwith the formula might be justified. For instance, where a national pay deal is agreed, and Scotland has a greater than population share of that public sector group, it would be relatively under-funded. A similar financial 
difficulty would occur where one service is undertaken by the public sector in Scotland but not in England, Scottish Water for instance.

Midwinter (2002, p.108) presents the bargaining theory in a strong form. He asserts that 'Scotland's share of UK public expenditure reflects a whole range of decisions, not just the mechanical application of the formula.' He extends Heald's argument, placing reduced emphasis on the formula and rather more on the bargaining: that is to say, his position seems to be "bargaining plus formula" rather than "formula plus bargaining”. Midwinter's stance is clearly consistent with that of Dunn (Official Report, 2002) cited in the previous section.

The bargaining procedures outlined by Heald and Midwinter imply that the devolved administrations might be able to attract a greater share of public expenditure than is consistent with their level of economic prosperity (MacKay, 2001; McLean and McMillan, 2003). Alesina and Spolaore (1997; 2003) put forward theoretical arguments as to why such differential treatment might be expected. The larger a country's size, the lower the per capita cost of providing national public goods as the fixed costs are shared amongst a larger population. However, expanding the territorial size of a country will also tend to increase its cultural and economic diversity. In their account, the more peripheral a region, the greater both the geographical and cultural distance from the provision of national public goods. With a single national tax structure, the benefits from a unified country are therefore distributed in a regionally differentiated way. This can mean that some territories have a possible incentive to secede. Essentially in their basic 
model, the size of country that maximises average welfare is larger than the size that would be produced through democratic decision making. That is to say, secession can improve welfare in the seceding region whilst simultaneously having a detrimental impact on total welfare.

Within the UK it is not difficult to recognise this issue. All of the three peripheral regions, Northern Ireland, Scotland and Wales, have cultural characteristics that are very distinct from the other (English) regions of the UK. Also each has significant political parties that seek secession from the union. In the case of Scotland, there are key institutional differences: separate legal and educational systems, and a differentiated religious structure. Further, at the time of writing the Scottish National Party, a party favouring Scottish independence, leads a minority administration in the Scottish Parliament. Clearly these cultural characteristics, created through specific historical forces, will have their own separate impacts but here reinforce the more mechanical Alesina and Spolaore argument.

Alesina and Spolaore (2003) suggest two solutions to this problem. Providing that transfers do not lead to significant economic distortions, it might be optimal to make transfers from central to peripheral regions. Alternatively, public good delivery might be decentralised. Again there is tangible evidence to both these proposals from the UK. The creation of the post of Minister of State, then Secretary of State for Scotland and finally the Scottish Parliament to Scotland, and the provision of devolved rule in Northern Ireland, until it was suspended in 1972 and then its intermittent reestablishment since 
1998, represent a decentralising of public good provision. The much later creation of the Welsh Office in 1964 and the highly marginal 1999 pro-devolution vote in Wales may serve to indicate both its closer geographical and social proximity to the 'centre'.

In addition, Northern Ireland, Scotland and Wales have higher per capita identifiable expenditure than England. The HM Treasury Needs Assessment (HM Treasury, 1979) showed needs indices for a similar level of provision for the public services that were to be devolved under the 1976 plans. These plans gave higher spending per head respectively to Wales, Scotland and Northern Ireland, figures all above the per capita spending level in England. These identifiable expenditure figures remain higher today, as shown in Section 2.1, even though the Barnett formula should encourage convergence. The UK therefore exhibits both of Alesina and Spolaore's projected outcomes.

Given this argument, it is of interest to attempt a ballpark figure of how large the payment to the peripheral regions might be. In Appendix 2 we develop a very simple accounting model in which: the nation is divided into central and peripheral regions where the proportion of the population in the peripheral region is $\gamma$; all individuals have equal incomes; and the tax system is uniform across the economy. In this model, government expenditure is divided between local and national public goods, where the proportion of total government expenditure made on national public goods is $\alpha$. The question that we pose is: what is the additional expenditure per head that the centre would 
be prepared to provide for local public goods in the periphery in order to retain the contribution of the peripheral regions to the funding of national public goods?

We identify the ratio of per capita expenditure on local public goods in the peripheral region compared to the central region as $\varepsilon$. In this model, those living in the centre benefit from the union as long as $\varepsilon$ is less than some maximum figure, $\bar{\varepsilon}$, given as: $^{11}$

$$
\bar{\varepsilon}=1+\frac{\alpha}{1-\alpha-\gamma}
$$

The value of $\alpha$ is difficult to determine accurately but we have used as an approximation the ratio of Non-Identifiable Expenditure to Total Managed Expenditure. HM Treasury (2006, p. 93) defines Non-Identifiable Expenditure as that 'deemed to be incurred on behalf of the United Kingdom as a whole, e.g. defence expenditure, overseas representation, tax collection and some environmental protection spending'. It is the residual of spending undertaken by the government that has been identified as benefiting the people, businesses or communities in a region. ${ }^{12}$ For the financial year $2004 / 5$, the UK Total Managed Expenditure was $£ 491$ billion, with Non-Identifiable Expenditure at $£ 64$ billion. This gives a value of $\alpha$ of $13 \%$. The data for population is rather more straightforward. For mid 2006, the Scottish population was 5.1 million out of a UK total of 60.6 million, giving a value of $\gamma$ of just over $8 \%$ (National Statistics Online, 2007). This generates a value of $\bar{\varepsilon}$ for Scotland equal to $116 \%$. This is very similar to the actual average differential that we calculate for Scotland in Section 2.1. ${ }^{13}$ 
The Alesina and Spolaore argument is primarily based on efficiency criteria, though this can also be supported by an appeal to a form of "territorial justice". First, if a country's size is determined solely on democratic principles, so that individual regions decide whether to enter or leave existing countries, although the average welfare per person falls, the minimum welfare experienced by any individual is increased. Under Rawlsian criteria, welfare has risen (Rawls, 1971). Transfers from the centre to the periphery are an attempt to maintain the overall efficiency of the economy, but in doing so they also mprove the relative welfare of those located at the periphery.

Second, Binmore $(1994 ; 1998)$ argues that our notions of justice and fairness essentially reflect the bargaining position of individuals and groups. Applying Binmore's general argument to this particular case, the additional public sector provision in the peripheral regions can be justified in terms of their physical and cultural distance from the centre. But many disadvantaged groups do not get such favourable treatment. In this case, the possibility of secession and the implied bargaining power strengthens the argument. However, this approach suggests a mechanism rather more systematic than that identified by Heald, perhaps closer to the position adopted by Midwinter.

\section{Formula plus influence}

If this bargaining approach is accepted, another puzzle appears. Why have the Barnett formula at all? In conventional bargaining theory, the outcome can be affected by 
varying the fall back position or the bargaining strength of either player (Dixit and Skeath, 1999, ch. 16). With a "bargaining plus formula" approach, the most straightforward interpretation might be that the formula determines the fall back position for all players - the situation to which all players revert if they fail to reach an agreement. ${ }^{14}$ But the allocation of a budget is a zero-sum game. Therefore the players would always be forced back to the formula outcome. This is because with any other bargain, at least one player would be worse off than their formula allocation and would therefore not accept the bargain.

In the case of Barnett, imagine that as a result of a strong bargaining position the peripheral regions could increase their share of the national budget. If these regions are really bargaining with the central government and the Barnett formula offers a fall back position, the central government would simply impose the formula. Similarly, if the central government had a bargaining position stronger than that suggested by the Barnett formula, the peripheral regions would just fail to reach an agreement so that the Barnett formula would need to be enforced. Either way, the outcome is the Barnett allocation. But this is exactly the result that authors such as Midwinter are attempting to avoid. By introducing bargaining into the situation, they are attempting to provide a mechanism for moving the actual outcome away from the formula.

Of course, the formula might simply be cosmetic, veiling the real processes at work: "an effective smokescreen" (MacKay, 2001, p. 573). But if the motivation is simply misdirection for those in the English regions, why was the mathematical operation 
of the formula initially hidden? Further, in practice, if this is central government spin perpetrated by both Labour and Conservative governments - it operates very imperfectly. For the Barnett process receives much criticism in the devolved administrations over something that has apparently not happened - convergence in public spending per head. ${ }^{15}$ Clearly, a straight bargaining account will accommodate the lack of convergence but raises problems of its own.

We wish to suggest a procedure that starts from the Barnett formula, but formally incorporates influence behaviour (Becker, 1983; 1985). We call this a "formula plus influence" system. We first outline our position in broad-brush terms and then discuss the details. In our approach, as far as the UK peripheral regions are concerned, the Barnett formula generates a floor allocation of funds. However, these administrations additionally use resources in an attempt to augment this allocation through influence behaviour. Whilst the Barnett formula operating alone produces convergence in per capita public expenditure, the impact of the influence behaviour is to generate additional revenues that are then incorporated into the base for allocations in subsequent years.

Through varying its responsiveness to this influence behaviour, the central government can determine the overall allocation of funds to the peripheral regions. Therefore central government can maintain a desired relative per capita public expenditure ratio that replicates what would be expected from the two sides' bargaining positions, as in Alesina and Spolaore (2003). Appendix 3 gives a mathematical demonstration of this result. This appendix shows that with a constant population and a 
fixed growth of nominal English public expenditure, appropriate central government behaviour in the "formula plus influence" system leads to the devolved administration spending a fixed proportion of its revenue on influence behaviour in order to maintain a fixed relative per capita expenditure differential over time.

It is perhaps important to stress at this point the differences between our approach and previous accounts of the allocation of budgets to the UK peripheral regions. First, we emphasise the importance of considering the allocation mechanism as a whole: that is, as a set of interacting institutional arrangements (Greif, 2006). The corollary is that to focus solely on one aspect of the allocation arrangement in isolation is to miss key elements of, and therefore completely misunderstand, the overall process.

Second, whilst there are likely to be short-run fluctuations in the allocations, which reflect the flexibility of the procedure, we expect that the ratio of the relevant per capita public expenditure figures to be relatively stable across time. This is because in the "formula plus influence" account, these ratios reflect the relative bargaining positions of the peripheral regions. But the institutional difficulties that would accompany secession are such that in bargaining, the long-run benefits and costs of union to both sides should determine the outcome. We would not expect these long-run benefits and costs to vary widely in the short run. ${ }^{16}$

Third, it is unlikely that the "formula plus influence" system has been consciously designed to bring about this outcome. In particular the Barnett formula was introduced 
initially as a stop-gap measure. Rather the interaction and adjustment of institutional arrangements that were put in place to meet rather different needs has produced this stable allocative outcome. This is clearly Midwinter's view: the existing procedures should be judged by their actual outcome, not by some theoretical projection of how the individual elements work in isolation.

\subsection{Consistency with the evidence}

A key characteristic of the "formula plus influence" version of the operation of Barnett is that it more satisfactorily accommodates the existing evidence than do alternative accounts. We begin with the evidence that is inconsistent with the strict application of the Barnett formula. First, within the "formula plus influence" system, the lack of empirical support of convergence is straightforward. The formal inclusion of influence activity means that the budget outcomes for the devolved administrations will always be greater than a strict application of the Barnett formula would predict.

Second, there is no inconsistency in the views of insiders that the operation of the Barnett formula is not meant to generate convergence. As we show in Appendix 3, central government can calibrate its response to influence behaviour so as to maintain the relative per capita public expenditures and the available evidence suggests this is broadly what has occurred, at least in the case of Scotland. 
Third, where the system works with a combination of formula and influence, the benefits of external transparency are questionable. Rather, the overall effectiveness of the system depends on a degree of opacity. In particular, the central government might have difficulty in formally acknowledging that the allocation process is systematically open to influence behaviour from the peripheral regions. Further, it might be inconvenient that there are explicit or implicit targets for relative per capita public expenditure differentials that the central government is choosing to maintain. Recall that the arguments presented by Alesina and Spolaore (2003) link the more powerful bargaining position of the peripheral regions with their credible ability to secede.

We now turn to the evidence presented against the pure bargaining solution. First, in the "formula plus influence" version of the budget allocation process, the formula still plays an important role. By focusing attention on marginal changes, it reduces overall influence costs and by setting a floor to the actual budget it gives a high degree of stability to the finances of the devolved administrations. This means that the details of the formula are important and we would expect revision from time to time. Second, the fact that the Barnett formula acting alone would produce convergence is crucial for the "formula plus influence" system. For example, if the formula by itself maintained the relative per capita public expenditures, then any additional influence behaviour would increase these relativities. Because the influence behaviour is unidirectional, it is important that the rule-based outcome undershoots any desired target. Such undershooting in this case means that the use of the formula alone implies convergence. 
4.2 Strengths of the formula plus influence system

The "formula plus influence" system is consistent with the evidence that other accounts of the UK allocation of funds to the peripheral regions find difficult to explain. Further, there are three potential advantages from such a system: improved flexibility, greater political integration and increased information flows.

In incorporating influence, the flexibility of the allocation system is improved. A formula-based system operates as a rule of thumb that by definition cannot adapt to unforeseen circumstances. Even if the formula has broad agreement initially, it will lose support if it is perceived to become unfair over time. But the economy is subject to spatially asymmetric short-term and long-term shocks, such as the onset of Foot and Mouth disease or the impact of differential population growth, which strain the formula. A strictly applied rules-based system trades off flexibility for increased certainty and reduced influence costs. However, the inflexibility of such an approach is likely to become more costly over time and might ultimately threaten the viability of the allocation system. Then the possibility of renegotiating the formula negates the advantages that the rules-based system appears to offer: significant influence costs and uncertainty again arise. Similar problems are discussed at depth in the literature on rules-based regimes for monetary policy (Balls et al, 2002; Drazen, 2000).

Allowing influence behaviour to affect outcomes in a controlled way potentially improves the integration of peripheral regions into the national political system. The 
regional administrations can be seen to be operating in the interests of the local population in attempting to increase funding for issues of local importance. For instance, Ian Lang (2002, p. 194), reflecting on his period as Secretary of State for Scotland, maintains that

... [t]he real scope for protecting Scottish interests lay in the side deals and the special ad hoc negotiations that stood outside the corral of the "bloc and formula"... The very existence of the Barnett formula, far from inhibiting me, enabled me to concentrate on special deals to augment our resources.

Similarly the centre can be seen to be reacting in a relevant manner - with cash - to what are taken to be the most important needs of the peripheral regions. This is of particular importance pre-devolution in bolstering the legitimacy and credibility of the locally unelected administrations, and gains significance given the limited independent taxraising powers of the peripheral regions, both pre- and post-devolution.

Finally, influence behaviour provides important information to the central government. It gives an incentive to the peripheral regions to signal their problems and priorities.

5. The Barnett procedure post-devolution 
The Barnett formula was maintained as the mechanism for financing the UK devolved administrations in the peripheral regions. However, this does not mean that the operation of the "formula plus influence" system has been unaffected. For whilst the relatively favourable public expenditure position of the devolved administrations stems from their peripheral status, and the potential bargaining power this gives, the particular administrative arrangements for delivering this outcome are of equal importance. In this respect, devolution has at least three key implications for the mechanism determining the funding levels to the devolved Parliament and Assemblies.

First, it is inconceivable that the operation of the formula remains opaque and not subject to external verification. Devolution, and the increase in financial information that has accompanied it, has led to an increase in the visibility of the Barnett formula and greater scrutiny of the formula's outcome and its method of operation. MacKay (2005) emphasises this point. There is no evidence that this scrutiny will reduce as devolution becomes embedded: in fact it seems more likely to increase. Given that Barnett operates through formula plus influence, this will destabilise the whole procedure. ${ }^{17}$

Second, devolution reduces the potential for influence activity in Westminster and Whitehall. For example, at the time of writing the role of Secretary of State for Scotland is curiously combined with that of Defence Secretary in the UK cabinet. With a separate First Minister in the Scottish Parliament, it seems unlikely that the UK cabinet spends much time on Scottish affairs. Further, where powers have been devolved to the Scottish Parliament, civil servants will have less contact with their counterparts in the 
corresponding Whitehall departments. Therefore the ability to affect budgetary decisions in Scotland's favour is likely to be reduced.

Third, devolution has almost certainly increased the notional bargaining power of the now devolved administrations through making secession organizationally more straightforward. However, as we argue above, it has simultaneously weakened the ability of the "formula plus influence" mechanism to maintain the differentially favourable funding levels of the devolved regions. This suggests that the Barnett formula will remain a source of friction in the devolved settlement: what was a robust, but flexible, funding mechanism pre-devolution might prove inadequate for the post-devolution world.

The increased concern over the Barnett formula has led to alternative financing mechanisms being put forward. Many involve a certain degree of fiscal autonomy, which raises issues beyond the scope of this paper (Ashcroft et al, 2006; Hallwood and MacDonald, 2005, 2006). Schemes that retain the full funding of the peripheral regions by the central government typically include a needs assessment. However, there are clear tensions raised in replacing the present funding mechanism for the now devolved administrations with one based on a needs assessment exercise that could equally apply to the English regions (McLean and McMillan, 2003).

First, the following statement by Ros Dunn indicates that HM Treasury are aware that devolution undermines the notion of a standard set of needs that should be met in each region. 
$[\mathrm{P}]$ art of the point about devolution was to allow for the devolved countries to have policy evolving in different ways to meet their own circumstances, so when you come to think about what would be a uniform level, the answer is do you say that the policy approach in England is the one we should standardise on, or the policy approach in Scotland, and so on. So I think there are some very complicated issues underlying that, and the argument I think would be that what we have is a reasonable distribution method that has commanded acceptance (Minutes of Evidence, House of Lords Select Committee on the Constitution, Answer to Question 1266, Wednesday 26th June, 2002).

Under devolution, it is not clear whose definition of needs should count. In some of the recent literature it is suggested that simple criteria, such as regional value added per head is an appropriate measure of need but this is extremely questionable (Bell and Christie, 2007). Any needs assessment would have to be based on a weighted index with the weights extremely difficult to objectively determine.

Second, the present asymmetric decentralised governance framework in the UK implicitly recognises the separate status of the devolved administrations. This separate status has a long history that predates devolution (see Appendix 1). The peripheral regions have a greater cultural distance from, and a greater bargaining power with, central government than the English regions. There is no necessity that the English 
regions should ever want or have the same degree of political independence experienced by the presently devolved administrations (Hazell, 2006; Rallings and Thrasher, 2006). ${ }^{18}$

\section{Conclusions}

In the debate concerning the funding of the now devolved peripheral regions, the Barnett formula is often presented as a mechanism that is so fundamentally flawed that almost any reasonable alternative would be an improvement. This view is wrong. Barnett is only one element in a more nuanced "formula plus influence" system that has many advantages for both central government and the peripheral regions. Remember that the Barnett formula has been in place for 30 years and was preceded by an allocation system that appeared to operate, in practice, in a very similar manner.

Although the Barnett formula was retained after devolution, many of the other key institutional elements of the "formula and influence" system changed. This has led to a questioning of the Barnett mechanism in both central and peripheral regions. In the debate over Barnett, the disparity between the outcome that Barnett would produce if it operated in isolation and the actual outcome that has resulted from the "formula plus influence" mechanism, of which Barnett is a part, have been misused on both sides. It is not the Barnett formula but the UK government that has retained the favourable funding position for the peripheral regions. Similarly, there has been no Barnett squeeze on 
funding to the peripheral regions, as would have occurred had Barnett been rigorously applied and been operating in isolation.

If it seeks to reform or replace Barnett, the government faces an extremely difficult task. The conventional response to the requirement for transparency and equity of treatment across all the regions of the UK is that some needs assessment procedure should be adopted (HM Treasury, 1979). It is generally thought that such an exercise would give peripheral regions a higher expenditure per head on local public goods than the UK average, although the difference would be lower than at present (MacKay, 2001, 2005; McLean and McMillan, 2003). ${ }^{19}$ However, in our view the budgets to the peripheral regions for local public goods have in the past offset the lower value to these regions of national public goods. This reflects the greater cultural and geographic distance of these regions from the centre and the greater political coherence and the more powerful bargaining power that the peripheral regions held. An appropriate solution will be difficult to find. 
Appendix 1: The history and mechanics of the Barnett formula

The Barnett formula has a predecessor in the Goschen formula. Named after the Chancellor of the Exchequer in office when it was introduced in 1888, this formula was used until 1959 (Heald and McLeod, 2002). It operated by allocating funds on the following basis: $80 \%$ to England and Wales, $11 \%$ to Scotland and $9 \%$ to Ireland (until Ireland achieved self government). After 1918 Scotland received 11/80ths of increments to relevant English public expenditure over the level paid in 1913-14 (McPherson and Raab, 1988). These proportions were based on the contribution of probate duties to the Exchequer - rather than the population shares - at the time of the formula's introduction (Mitchell, 1991). Funding for Northern Ireland operated somewhat differently. Post 1920 the province was supposed to make an imperial contribution to Westminster as payment for those services provided by the UK government that benefited Northern Ireland. In fact this quickly became an effective imperial subsidy, as Stormont (the Northern Irish government) was never in a position to afford such a contribution and the flow of funds was reversed (Mitchell, 2004).

Between 1959 and 1978 there was no formally acknowledged mechanism to allocate resources to the peripheral regions. Heald and McLeod (2002, p. 458) note that it would have been difficult to cast aside immediately the Goschen formula and "that 11/80ths of England and Wales provision may have been seen as a minimum." This system remained in place until the inception of the Barnett formula in 1978. (Heald (1980) christened the formula after Joel Barnett, who was Chief Secretary to the Treasury 
when the formula was introduced.) However, the Barnett formula was the second choice allocation mechanism to a needs assessment. As part of the proposal to establish devolved assemblies for Scotland and Wales, the intention was to use a formula system based upon a needs assessment for those functions that were to be devolved. More importantly, the needs-based formula was to be settled after consultation with the devolved Assemblies.

The Barnett formula appears to have been devised by the UK Treasury and imposed on the peripheral regions. Since it was only considered to be an interim arrangement, this might have reduced any resistance from the Scottish and Welsh Offices. But the failure of devolution and the election of the strongly anti-devolutionist Conservative government meant that the Barnett formula was retained and rapidly became institutionalised, though little publicised. 
Appendix 2: The Costs of Secession

Imagine a unified country, subscript $U$, with a central and peripheral region, subscripted as $\mathrm{C}$ and $\mathrm{R}$ respectively. Government expenditure, $\mathrm{G}$, is divided between national and local public goods ( $\mathrm{N}$ and $\mathrm{L}$ ). The public sector has a balanced budget, with a constant per capita tax rate $\mathrm{t}$, and the proportion of the budget spent on national public goods is $\alpha$. Population is $\mathrm{P}$, with the proportion in the peripheral region as $\gamma$. For the unified economy the tax rate is given as:

$$
t_{U}=\frac{N+L_{C}+L_{R}}{P_{C}+P_{R}}
$$

For the centre, if the peripheral region secedes, the tax rate is

$$
t_{C}=\frac{N+L_{C}}{P_{C}}
$$

The central population is better off retaining the periphery within the union as long as:

$$
t_{C} \geq t_{U}
$$

Substituting (A2.1) and (A2.2) into (A2.3) gives the required inequality as:

$$
\frac{N+L_{C}}{P_{C}} \geq \frac{N+L_{C}+L_{R}}{P_{C}+P_{R}}
$$

which can be reformulated as:

$$
\frac{N+L_{C}}{P_{C}} \geq\left[\frac{N+L_{C}}{P_{C}}\right]\left[\frac{P_{C}}{P_{C}+P_{R}}\right]+\frac{L_{R}}{P_{C}+P_{R}}
$$

which simplifies to: 
(A2.6)

$$
\left[\frac{N+L_{C}}{P_{C}}\right]\left[\frac{P_{R}}{P_{C}+P_{R}}\right] \geq \frac{L_{R}}{P_{C}+P_{R}}
$$

Multiplying both sides of expression (A2.6) by $\frac{P_{C}+P_{R}}{P_{R}}$ produces:

$$
\frac{N}{P_{C}}+\frac{L_{C}}{P_{C}} \geq \frac{L_{R}}{P_{R}}
$$

Define the proportionate difference between the expenditure on local public goods between the centre and peripheral regions as $\varepsilon$, so that:

$$
\frac{L_{R}}{P_{R}}=\varepsilon \frac{L_{C}}{P_{C}}
$$

where we expect $\varepsilon>1$. Combining (A2.7) and (A2.8) and rearranging produces:

$$
N \geq(\varepsilon-1) L_{C}
$$

Given the share of the national public good in total government expenditure and the proportion of the population in the peripheral region, the value of the expenditure on local public goods in the central region is given as:

$$
L_{C}=\frac{G(1-\alpha)(1-\gamma)}{1+\gamma(\varepsilon-1)}
$$

Combining equations (A2.9) and (A2.10) gives:

$$
\alpha \geq \frac{(\varepsilon-1)(1-\alpha)(1-\gamma)}{1+\gamma(\varepsilon-1)}
$$

Rearranging (A2.11), for values of $1>\alpha+\gamma$, produces the maximum value for $\varepsilon(\bar{\varepsilon})$ for which the centre still gains from the union, so that:

$$
\bar{\varepsilon}=1+\frac{\alpha}{1-\alpha-\gamma}
$$


Appendix 3: A Mathematical Representation of the Formula and Influence System

In period $t$, the ratio of peripheral to central public expenditure per head, $m$, is given as:

$$
m=\frac{A_{t}}{G_{t} \sigma}
$$

where $A_{t}$ is the actual peripheral real allocation of funds through the Barnet mechanism, $\mathrm{G}_{\mathrm{t}}$ is the comparable central real public expenditure figure, $\sigma$ is the peripheral population measured relative to the central total and the subscript $t$ indicates the time period. (The population ratio is assumed to be unchanged over time). Given that the peripheral region has a relatively high per capita public expenditure, $\mathrm{m}>1$. Under what circumstances will a combination of the Barnett formula plus influence behaviour, regulated by the central government, maintains the value of m constant over time?

The administration in the peripheral region can use real resources in period $t, \mathrm{I}_{\mathrm{t}}$, to influence the budget allocation from central government by a real amount, $\mathrm{E}_{\mathrm{t}+1}$, in the subsequent year. We take the impact of this influence activity to be governed by the general relationship:

$$
\frac{E_{t+1}}{B_{t+1}}=Z\left[\frac{I_{t}}{A_{t}}\right]^{\alpha}
$$

where $B_{t+1}$ is the real Barnett counterfactual allocation of resources in period $t+1$, and $Z$ $(>0)$ and $\alpha(1>\alpha>0)$ are at present treated as parameters. By the counterfactual Barnett allocation we mean the allocation in period $t+1$ that would follow from $A_{t}$ without influence activity. 
Equation (A3.2) can be also be expressed as:

(A3.3)

$$
E_{t+1}=K_{t}\left[I_{t}\right]^{\alpha}
$$

where:

$$
K_{t}=\frac{Z B_{t+1}}{A_{t}^{\alpha}}
$$

and

$$
\frac{d E_{t+1}}{d I_{t}}>0, \frac{d^{2} E_{t+1}}{d I_{t}^{2}}<0
$$

However, the benefits to the peripheral administration do not stop in period 1: any improvement in funding in one period is continued in nominal terms into all subsequent periods, as it becomes built into the Barnett formula outcomes.

The forward-looking peripheral administration sets the value of $I_{t}$ in order to maximise the present value, $\Pi_{t}$, of public sector consumption. This is given as:

where $C_{i}$ is real public consumption in period $i$ and $\delta$ is the time discount factor $(0<\delta$ $<1)$. For the initial period, that is where $\mathrm{i}=\mathrm{t}$ :

$$
\Pi_{t}=\sum_{i=t}^{\infty} \delta^{i-t} C_{i}
$$

For subsequent periods, where i $>$ :

$$
C_{i}=A_{i}=B_{i}+\frac{E_{t+1}}{(1+\rho)^{i-t-1}}
$$


where $\rho$ is the rate of inflation. The additional funding generated by the influence behaviour in period $\mathrm{t}$ is discounted by the inflation rate because the Barnett formula operates in nominal terms.

Combining equations (A3.3) to (A3.7) gives:

$$
\Pi_{t}=A_{t}-I_{t}+\sum_{i=t+1}^{\infty} \delta^{i-t} B_{i}+K_{t} I_{t}^{\alpha} \sum_{j=t+1}^{\infty} \frac{\delta^{j-t}}{(1+\rho)^{j-t-1}}
$$

that can be restated as:

$$
\Pi_{t}=A_{t}-I_{t}+\sum_{i=t+1}^{\infty} \delta^{i-t} B_{i}+K_{t} I_{t}^{\alpha}\left[\frac{\delta(1+\rho)}{1+\rho-\delta}\right]
$$

Partially differentiating equation (A3.9) with respect to $I_{t}$ and setting this to zero gives the investment in influence that maximises present value of real public consumption in the peripheral region:

$$
I_{t}=\left[\frac{K_{t} \alpha \delta(1+\rho)}{1+\rho-\delta}\right]^{\frac{1}{1-\alpha}}
$$

Substituting equation (A3.10) into equation (A3.3) and using equation (A3.4) gives the real increase in central government funds received in period $t+1$ as a result of this optimal influence activity by the peripheral administration:

$$
E_{t+1}=K_{t}^{\frac{1}{1-\alpha}}\left[\frac{\alpha \delta(1+\rho)}{1+\rho-\delta}\right]^{\frac{\alpha}{1-\alpha}}=\left[\frac{Z B_{t+1}}{A_{t}^{\alpha}}\right]^{\frac{1}{1-\alpha}}\left[\frac{\alpha \delta(1+\rho)}{1+\rho-\delta}\right]^{\frac{\alpha}{1-\alpha}}
$$

The parameter $\mathrm{Z}$ can be treated as a central government policy instrument, with variations in the parameter $\mathrm{Z}$ corresponding to the central government's varying its receptiveness to the devolved administrations. But can the value of this influence- 
behaviour efficiency parameter, $\mathrm{Z}$, be set so as to maintain the peripheral relative public expenditure per head constant, as against the English figure?

The counterfactual peripheral Barnett allocation for the period $t+1$, that is the allocation without influence behaviour, is calculated as follows. The peripheral region receives its nominal budget for the previous year plus a share of the change in the central nominal budget. This share is proportional to the peripheral region's population. If the proportionate increase in real national government expenditure is $\mathrm{g}$, and the inflation rate is $\rho$, then the change in nominal central government expenditure, $\Delta \mathrm{G}_{\mathrm{t}+1}{ }^{\mathrm{N}}$, is given as:

$$
\Delta G_{t+1}^{N}=G_{t}(1+\rho)(1+g)-G_{t}=G_{t}(\rho+g+\rho g)
$$

Using equations (A3.1) and (A3.12), the counterfactual Barnett allocation is therefore:

$$
B_{t+1}=\frac{A_{t}+\sigma \Delta G_{t+1}^{N}}{1+\rho}=\frac{G_{t} \sigma m+G_{t} \sigma(\rho+g+\rho g)}{1+\rho}=\frac{G_{t} \sigma(m+\rho+g+\rho g)}{1+\rho}
$$

Again, using equation (A3.1), equation (A3.13) can be expressed as:

$$
B_{t+1}=\frac{A_{t}(m+\rho+g+\rho g)}{(1+\rho) m}
$$

The required increase in the budget generated by influence behaviour in order to maintain the real value of the peripheral allocation (and therefore its relatively favourable position in terms of per capita expenditure) is given by:

$$
\frac{E_{t+1}+B_{t+1}}{G_{t} \sigma(1+g)}=m
$$

Rearranging equation (A3.15) and using equation (A3.13) and (A3.1) produces: 
(A3.16)

$$
E_{t+1}=\frac{G_{t} \sigma}{1+\rho}(m(1+g)(1+\rho)-m-g-\rho-\rho g)=\frac{A_{t}}{(1+\rho)}\left[\frac{(m-1)(g+\rho+\rho g)}{m}\right]
$$

Equation (A3.16) indicates the funding required, additional to that coming through the strict application of the Barnett formula, to maintain the relatively favourable peripheral per capita public expenditure. The corresponding equation for $\mathrm{E}_{\mathrm{t}+1}$ derived from the maximising behaviour of the peripheral administration is found by combining equation (A3.14) and (A3.11) to give:

$$
E_{t+1}=\frac{A_{t}}{(1+\rho)}\left[\frac{Z(m+\rho+g+\rho g)}{m}\right]^{\frac{1}{1-\alpha}}\left[\frac{\alpha \delta}{1+\rho-\delta}\right]^{\frac{\alpha}{1-\alpha}}
$$

If equation (A3.17) is substituted in equation (A3.18), we can derive the value of $\mathrm{Z}$, the influence-effectiveness parameter, which will maintain the value of the relative per capita public expenditure, $\mathrm{m}$, constant. This is:

$$
Z=\frac{[(m-1)(g+\rho+\rho g)]^{1-\alpha}[m(1+\rho-\delta)]^{\alpha}}{(m+\rho+g+\rho g)(\alpha \delta)^{\alpha}}
$$

Whilst the expression on the RHS of equation (A3.18) is rather complex, it is independent of the scale of the initial Barnett allocation. Therefore in period $t+1$, when the peripheral administration again has to take the decision about influence activity, it will allocate the same share of its budget with the same relative effects on the allocation in future rounds. 


\title{
Acknowledgements
}

The authors would like to thank John McLaren, Peter McGregor, James Mitchell, Arthur Midwinter Andy Park, participants at the Scottish Economic Society Annual Conference, Perth, 2006 and the Regional Science Association, British and Irish Section, Annual Conference, Jersey, 2006 and four anonymous referees for comments on this and earlier related works.

\section{References}

Acemoglu, D. and Robinson, J.A. (2006) Economic Origins of Dictatorship and Democracy, Cambridge University Press, Cambridge.

Ashcroft B., Christie, A. and Swales, K. (2006) "Flaws and Myths in the Case for Scottish Fiscal Autonomy", Fraser of Allander Quarterly Economic Commentary, vol. 13 , no. 1 , pp. 33-39.

\begin{abstract}
Alesina, A. and Spolaore, E. (1997) "On the Number and Size of Nations", Quarterly Journal of Economics, vol. 112, pp. 1027-56.
\end{abstract}

\begin{abstract}
Alesina, A. and Spolaore, E. (2003) The Size of Nations, MIT Press, Cambridge, Massachusetts.
\end{abstract}


Bailey, S.J. and Fingland, L. (2004) 'Convergence of Public Expenditures in UK Territories', Regional Studies, vol. 38, pp. 845 - 858 .

Balls, E., O’Donnell, G. and Bhundia, A. (2002) “The UK Model of Central Bank Independence: An Assessment', in Balls, E. and O'Donnell, G., ed. Reforming Britain's Economic and Finance Policy, HM Treasury, Palgrove, Basingstoke, pp. 85-109.

Becker, G.S. (1983) 'A Theory of Competition among Pressure Groups for Political Influence,' The Quarterly Journal of Economics, vol. 98, pp. 371-400.

Becker G.S. (1985) 'Public Policies, Pressure Groups and Deadweight Costs' Journal of Public Economics, vol. 28, pp. 329-47.

Bell D. (2000) 'The Barnett Formula', mimeo, University of Stirling, Stirling.

Bell, D. and Christie A. (2007) "The Difficulty of Simple Needs Assessment in the UK" mimeo, University of Strathclyde, Glasgow.

Binmore, K. (1994) Game Theory and the Social Contract - Playing Fair, MIT Press, Cambridge, Massachusetts. 
Binmore, K. (1998) Game Theory and the Social Contract - Just Playing, MIT Press, Cambridge, Massachusetts.

Cuthbert, J. (1998) 'The Implications of the Barnett Formula', Saltire Paper No 1, Scottish National Party, Edinburgh.

Cuthbert, J. (2001) 'The Effect of Relative Population Growth on the Barnett Squeeze", Fraser of Allander Quarterly Economic Commentary, vol. 26, No. 2, pp. 34-37.

Dixit, A.K. and Skeath, S. (1999) Games of Strategy, Norton and Co., New York.

Drazen, A. (2000) Political Economy in Macroeconomics, Princeton University Press, Princeton, New Jersey.

Ferguson, L., McGregor, P.G., Swales, J. K., and Turner, K. (2003) 'The Regional Distribution of Public Expenditures in the UK: An Exposition and Critique of the Barnett Formula', Strathclyde Discussion Papers in Economics, 03-08.

Gallagher, J. and Hinze, D. (2005) "Financing Options for Devolved Government in the UK”, Discussion Paper 2005-24, Department of Economics, University of Glasgow.

Greif, A. (2006) Institutions and the Path to the Modern Economy, Cambridge University Press, Cambridge, UK. 
Hallwood, P. and McDonald R. (2005) 'The Economic Case for Fiscal Federalism', in D. Coyle, W. Alexander and B. Ashcroft, eds. New Wealth for Old Nations: Scotland's Economic Prospects, Princeton University Press, Princeton.

Hallwood, P. and McDonald R. (2006) "The Economic Case for Scottish Fiscal Autonomy: With or Without Independence”, Policy Institute, Edinburgh.

Hazell, R. (2006) “The English Question”, Publius, vol. 36, No. 1, pp. 37-56.

Hazell, R. (2008) “Salmond Has Far to Leap”, Prospect, July, 2008, p. 18.

Heald, D. (1980) 'Territorial Equity and Public Finances: Concepts and Confusion' University of Strathclyde Centre for the Study of Public Policy, Studies in Public Policy No.75.

Heald, D.A. (1994) 'Territorial Public Expenditure in the United Kingdom', Public Administration, vol. 72, pp. 147-75.

Heald D.A. and McLeod, A. (2002) 'Public Expenditure' in The Laws of Scotland: Stair Memorial Encyclopaedia, paragraphs 480-552, Butterworths, Edinburgh.

HM Treasury, (various), Autumn Statement, HMSO, London. 
HM Treasury, (various), Financial Statement and Budget Report, HMSO, London.

HM Treasury (various), Public Expenditure Statistical Analyses, HMSO, London.

HM Treasury (1979) Needs Assessment Study: Report, HMSO, London.

HM Treasury (2006) Public Expenditure Statistical Analysis 2006, London: HMSO.

Kay, N. (1998) 'The Scottish Parliament and the Barnett Formula', Fraser of Allander Quarterly Economic Commentary, vol 24, No. 1, pp. 32-48.

Lang, I. (2002) Blue Remembered Years: A Political Memoir, Politico's, London

MacKay, R.R. (2001) "Regional Taxation and Spending: The Search for Balance", Regional Studies, vol. 35, pp. 563-575.

MacKay, R.R. (2005) “Thinking About Need: Public Funding on the Regions”, Regional Studies, vol. 39, pp. 815-828.

McConnell, J. (2000) "Why Barnett Remains Better than the Alternatives", New Economy, vol. 7, No. 2, pp. 65-68. 
McGregor, P., and Swales, J.K. (2005) 'Economics of Devolution/Decentralization in the UK: Some Questions and Answers' Regional Studies, vol. 39, pp. 477-494.

McLean, I. and McMillan, A. (2003) "The Distribution of Public Expenditure across the UK Regions”, Fiscal Studies, vol. 24, pp. 45-71.

McPherson, A. and Raab, C.D. (1988) Governing Education: A Sociology of Policy since 1945, Edinburgh University Press, Edinburgh.

Midwinter, A. (1999) 'The Barnett Formula and Public Spending in Scotland: Policy and Practice', Scottish Affairs, No. 28, pp. 83-92.

Midwinter, A. (2002) 'The Limits to Fiscal Autonomy under the Devolution Settlement' Scottish Affairs, No.41, pp. 102-120.

Midwinter, A. (2004) 'The Changing Distribution of Territorial Public Expenditure in the UK" Regional and Federal Studies, vol. 14, pp. 499-512.

Mitchell, J. (1991) 'Scottish Public Finances', mimeo, University of Strathclyde, Glasgow. 
Mitchell, J. (2004) 'Financing Devolution: Stormont and the Welfare State.' Paper presented at the Conference of the PSA British and Comparative Territorial Politics Specialist Group 2004, University of Strathclyde, Glasgow.

National Statistics Online (2007), www.statistics.gov.uk

Official Report (1997) col. $510-513,9^{\text {th }}$ December, 1997.

Official Report (1998) Scottish Grand Committee, $21^{\text {st }}$ July 1998.

Official Report (2002) House of Lords Select Committee on the Constitution $26^{\text {th }}$ June 2002, Q1263.

Rallings C. and Thrasher M. (2006) ““'Just Another Expensive Talking Shop”: Public Attitudes and the 2004 Regional Assembly Referendum in the North East of England”, Regional Studies, vol. 40, pp. 927-936.

Rawls, J. (1971) A Theory of Justice, Harvard University Press, Cambridge, Massachusetts.

The Scotsman $24^{\text {th }}$ June, 2005. 


\section{Footnotes}

1 In the remainder of this paper we refer to this as relative public expenditure convergence.

${ }^{2}$ Initially the changes in the relevant expenditure totals were measured in real terms. This was changed to nominal terms in 1982.

${ }^{3}$ Scotland's population has fallen since the 1970s, and this was reflected in the updated population ratios in 1992. Since 1997, this updating has become annual, with the latest population estimates giving Scotland $10.32 \%$ of the English population, having fallen from $10.66 \%$ in the first update in 1992.

\footnotetext{
${ }^{4}$ Those parts of DEL on which the Barnett formula operates are given a comparability percentage from $0 \%$ to $100 \%$, which represents the extent to which the expenditure for that item is conducted by the devolved administration or by Westminster. This is then multiplied by the population percentage to arrive at an increment for each budget line; the sum of all budget lines being the Barnett-formula-determined increment to the devolved administration.
}

${ }^{5}$ That is to say, over time the ratio of the peripheral region's relevant public expenditure per head to the English comparable public expenditure per head tends to unity. 


\footnotetext{
${ }^{6}$ The degree of convergence implied by the formula will be positively related to the extent of spending covered, the rate of real public spending increases in England and the rate of inflation. If there is a falling population share in the peripheral region then this can slow the convergence process but this is of minor importance in this time period. A full mathematical treatment of the formula and squeeze can be found in Cuthbert (1998; 2001) and Bell (2000).
}

${ }^{7}$ Gallacher and Hinze (2005) consider two other sets of figures. They plot Scottish relative per capita aggregate and identifiable relative public expenditure over a longer time period (1980-2003) but find no convergence. They also calculate Scottish relative per capita health expenditure over a similar time period. This initially diverges from the English level and then converges, but these expenditures will be affected by a number of factors, not simply Barnett.

8 The data for early years come from the annual Autumn Statement (HM Treasury, various) and subsequently the Financial Statement and Budget Report (HM Treasury, various) after the publications were merged in 1992. Data for each year are the latest available, on the basis that these have the lowest discrepancy from actual budgets. The measures employed are the planning total for Scotland and the overall planning total for the UK. After the public sector's accounting system altered in 1998, the figures are for Scottish DEL and total UK DEL. 
${ }^{9}$ The value for the Wald-Wolfowitz Runs Test indicates that the sequence of increases and decreases in relative expenditure is not significantly different from random at the $10 \%$ significance level.

${ }^{10}$ One reason for failing to reveal an allocation formula might be so as to stop the participants "gaming the system". However, in this case, with the formula allocation being determined solely by the population share, that would not be a consideration.

${ }^{11}$ Equation (1) shows that where the peripheral region is very small, so that $\gamma \rightarrow 0$, the central government will be prepared to supply additional expenditure to cover local public goods up to a value of $\varepsilon$ equal to $\frac{1}{1-\alpha}$. This is the ratio of total public expenditure to public expenditure on local public goods. The maximum additional per capita expenditure is increased where the share of national public goods and the size of the potentially seceding peripheral region are larger given that $\frac{\partial \bar{\varepsilon}}{\partial \alpha}, \frac{\partial \bar{\varepsilon}}{\partial \gamma}>0$.

${ }^{12}$ However, some of the expenditure allocated to regions is actually to finance national public goods. An example is the wage costs of defence establishments.

${ }^{13}$ The calculated figures for Wales, $116 \%$, and Northern Ireland, 115\%, are very similar but slightly smaller, reflecting the lower population level in these regions. 
14 This is the role played by their amended Barnett formula in the scheme for allocation of government revenue to the UK regions put forward by McLean and McMillan (2003).

15 The formula also gets criticised in some English regions for maintaining intact the original additional per capita nominal expenditure advantage that the now devolved administrations had over the English average (McGregor and Swales, 2005).

16 See Hazell (2008) for an account of the difficulties facing the movement towards Scottish independence. However, Acemoglu and Robinson (2006) take rather a different position. They argue that short-run considerations have been important in the timing of the expansion of suffrage, though the commitment problems that drive their analysis seems less relevant here.

17 It is odd that many who wish to defend the Barnett process, for example Dewar (Official Report, 1998) and McConnell (2000), praise it for the transparency and simplicity that it does not have in actual operation.

${ }^{18}$ In saying this we do not wish to give any disservice to English regionalism. Clearly there are economic, social and cultural variations across English regions and there is a degree of decentralised policy making. But within England, the desire for political institutions at the regional level is at present very weak. 
${ }^{19}$ Because there has been no recent needs assessment, it is not possible to be categorical about this. For regions such as Scotland, differential expenditure on local public goods would reflect both the relative need and the cost of meeting that need, given that the greater spatial dispersion of the population increases transport costs and reduces the possibility of economies of scale and scope in the provision of public goods. 


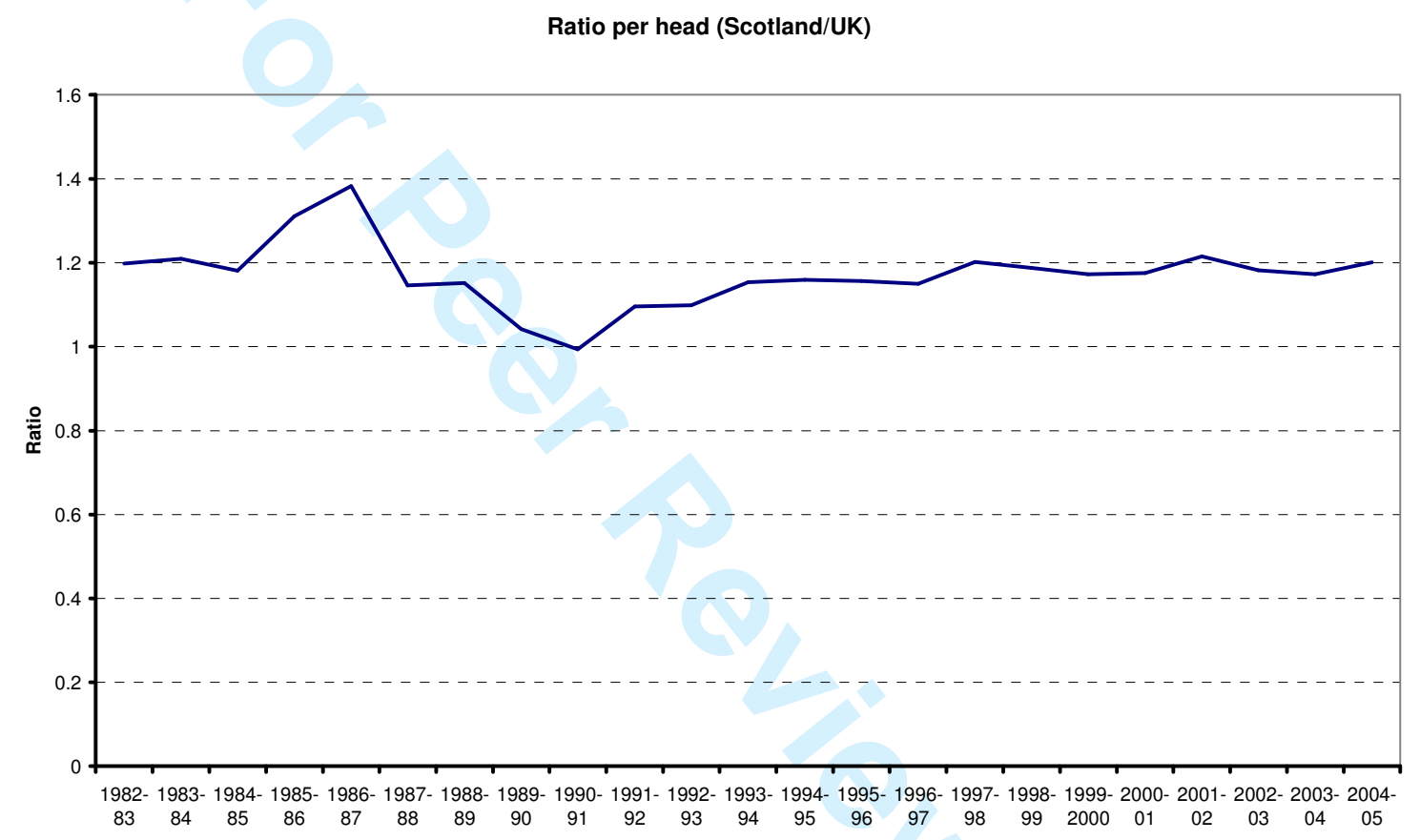

Figure 1: Relative budget allocation per head, Scotland-UK (1982-2005) 